\title{
Pengembangan pemakaian hasil samping agroindustri berbahan dasar jagung sebagai alternatif bahan baku pakan ikan kerapu tikus Cromileptes altivelis
}

\section{The utilization of corn industrial by product as an alternatif raw material for humpback grouper Cromileptes altivelis}

\author{
Muhammad Agus Suprayudi*, Dedy Yaniharto ${ }^{2}$, Hasan Abidin ${ }^{1}$, Nur Bambang Priyo \\ Utomo $^{1}$, Dedi Jusadi ${ }^{1}$, Mia Setiawati ${ }^{1}$ \\ ${ }^{1}$ Departemen Budidaya Perairan, Fakultas Perikanan dan Ilmu Kelautan, Institut Pertanian Bogor \\ Kampus IPB Dramaga Bogor 16680 \\ ${ }^{2}$ Badan Pengkajian dan Penerapan Teknologi \\ Jl. M.H. Thamrin no. 8, Jakarta 10340 \\ *email: agus.suprayudi@yahoo.com
}

\begin{abstract}
This experiment was conducted to evaluate the use of by product of corn ethanol industry, DDGS (distiller dried grain with soluble) and hominy as feed raw material on digestibility and the growth performance of humpback grouper Cromileptes altivelis juvenile. Three experimental diets containing isoprotein (48\%) but different in DDGS contain were used. Diet A containing 0\% of DDGS and hominy while diet B and C containing $10.13 \%$ (6.13\% of DDGS and 4\% of hominy) and 19.05\% (15.05\% of DDGS and $4 \%$ of hominy). Reduce of fish meal level in the diet was happen as a consequence of balancing amino acid. For digestibility experiment and $\mathrm{Cr}_{2} \mathrm{O}_{3}$ at level of $0.05 \%$ was used as a tracer. The feces were daily collected 30-60 minutes after feeding for 14 days. Dry matter and protein were used as digestibility parameters. Completely randomized design with three treatments and two replicates was used in this experiment. Humpback grouper with an average weight of 11-14 g were reared at floating net cages (FNG) of $3 \times 2 \times 1.5 \mathrm{~m}^{3}$. The stocking density for each cage was 167 fish/FNG and reared for six months. For digestibility measurement 30 fish were held in cylindrical fiber tank filled with $800 \mathrm{~L}$ of sea water. Fish were fed three times daily at satiation level. For maintaining net in a clean condition net was changed in every ten days. Feed consumption, digestibility of protein and total, growth performance indicator i,e specific growth rate, feed efficiency protein and lipid retention were used as evaluating parameters. The results showed that the fish fed with diet containing DDGS (6.13\%) dan hominy (4\%), at the level of $10.13 \%$ (diet B), shows similar growth performance indicators with the fish fed diet A (0\% of DDGS and hominy) and the growth performance indicator was higher when being compared to those fish fed diet C (containing $19.05 \%$ of DDGS $(15.05 \%)$ and hominy $(4 \%))(\mathrm{p}<0.05)$. More over the inclusion of DDGS and hominy at the level of 10,13\% give no negatif impact to feed palatability (shown by total feed consumption value) and digestibility of protein. The increasing level of DDGS and hominy more than $10 \%$ reduced palatability and protein digestibility. Based on this research, DDGS and hominy can be used up to $10 \%$ in the feed formulation of humpback grouper
\end{abstract}

Keywords: digestibility, growth performance, DDGS, hominy, humpback grouper, Cromileptes altivelis

\begin{abstract}
ABSTRAK
Penelitian ini dilakukan untuk mengevaluasi pemanfaatan limbah jagung dari industri etanol dalam bentuk distillate dried grain with soluble (DDGS) dan homini sebagai bahan baku pakan terhadap kinerja pertumbuhan ikan kerapu bebek Cromiliptes altivelis. Ikan yang digunakan dalam penelitian ini adalah juvenil ikan kerapu bebek berukuran 11-14 g. Ikan dipelihara dalam karamba jaring apung yang berukuran $3 \times 1,5 \times 2$ $\mathrm{m}^{3}$ dengan kepadatan 167 ekor/jaring. Ikan diberi pakan sampai kenyang sebanyak dua kali sehari. Untuk menjaga agar jaring tetap bersih maka dilakukan pergantian jaring setiap satu sampai dua minggu sekali. Ikan dipelihara selama lima bulan dan setiap bulan dilakukan sampling. Tiga macam pakan digunakan dalam penelitian ini dengan kadar protein $47 \%$ dan rasio energi protein $10 \mathrm{kkal} / \mathrm{g}$ protein. Pakan A adalah pakan yang tidak mengandung DDGS dan homini, pakan B mengandung DDGS 6,13\% dan 4\% (total 10,13\%), dan pakan C mengandung DDGS 15,05\% dan Homini 4\% (total 19,5\%). Untuk mengevaluasi ketercernaan nutrien maka kromium oksida $\left(\mathrm{Cr}_{2} \mathrm{O}_{3}\right)$ digunakan sebagai penelusur. Penelitian ketercernaan dilakukan di laboratorium dengan menggunakan fiber dengan volume $800 \mathrm{~L}$. Rancangan acak lengkap dengan tiga perlakuan dan dua
\end{abstract}


ulangan digunakan dalam penelitian ini. Hasil penelitian menunjukkan bahwa nilai ketercernaan nutrien tidak berbeda sampai total kadar DDGS dan homini 10,13\% (pakan B) dan peningkatan DDGS serta homini sampai 19,05\% (pakan C) menurunkan nilai ketercernaan. Ikan yang diberi pakan dengan DDGS sebesar 10,13\% (pakan B) memiliki nilai efisiensi pakan, sintasan, laju pertumbuhan spesifik, konsumsi pakan dan retensi protein yang sama dengan pakan tanpa DDGS (pakan A), akan tetapi nilai-nilai tersebut lebih tinggi jika dibandingkan dengan ikan yang diberi pakan $\mathrm{B}(\mathrm{p}<0,05)$. Retensi lemak ikan yang diberi pakan $\mathrm{B}$ memiliki nilai yang lebih tinggi jika dibandingkan dengan ikan yang diberi pakan A dan C. Dari penelitian ini dapat disimpulkan bahwa DDGS dan homini dapat digunakan sebagai bahan baku pakan ikan kerapu bebek sampai level 10,13\% (DDGS 6,13\% dan homini 4\%).

Kata kunci: pertumbuhan, ketercernaan, DDGS, homini, ikan kerapu bebek, Cromileptes altivelis

\section{PENDAHULUAN}

Pakan sangat penting dalam pengembangan usaha budidaya ikan karena biaya produksi budidaya ikan sistem intensif sangat ditentukan oleh biaya penyediaan pakan. protein dan karbohidrat merupakan komponen terbesar dalam pakan ikan (50-88\%). Pada umumnya, tepung ikan dan bungkil kedelai digunakan sebagai sumber protein, sedangkan untuk sumber karbohidrat digunakan gandum dan turunannya (Suprayudi, 2010). Saat ini produksi tepung ikan tidak mengalami kenaikan, namun kebutuhan akan tepung ikan meningkat drastis terkait dengan peningkatan produksi akuakultur. Disamping itu, terjadi kompetisi pemanfaatan ikan baik sebagai bahan baku pakan maupun makanan manusia. Hal ini berdampak meningkatnya harga tepung ikan menjadi hampir dua kali lipat, hal ini juga terjadi pada produk kedelai serta gandum dan turunannya (Hardy, 2006). Oleh karena itu penelitian ini dilakukan untuk mencari alternatif sumber protein dan karbohidrat yang relatif murah, berkualitas dan tersedia secara kontinyu. Distillers dried grain with solubles (DDGS) dan Hominy Feed (HF) merupakan hasil samping industri biofuel berbasis jagung yang jumlahnya sangat melimpah (Hertrampf \& Piedad-Pascual, 2000). Pada ternak dan beberapa jenis ikan air tawar yang bersifat herbivora dan karnivora, kedua bahan tersebut (DDGS dan HF) sudah terbukti efektif sebagai sumber protein dan karbohidrat alternatif pada ikan lele Clarias sp dan ikan bawal tawar (Tangendjaja \& Wina, 1998). Pada ikan lele hibrid DDGS dapat dimanfaatkan hingga level 30\% dengan penambahan lisin (Zhou et al., 2010). Namun demikian penggunaannya sebagai bahan baku pakan ikan kerapu belum dilakukan. Tujuan penelitian ini adalah untuk mengevaluasi pemanfaatan DDGS dan homini pada pakan juvenil kerapu bebek Cromileptes altivelis.

\section{BAHAN DAN METODE}

\section{Pakan penelitian}

Spesifikasi pakan yang digunakan dalam penelitian ini adalah protein $47 \%$, lemak minimum $10 \%$, karbohidrat maksimum $20 \%$, serat maksimum $8 \%$, dan abu maksimum $5 \%$. Berdasarkan spesifikasi nutrien yang sudah ditetapkan maka dibuat tiga macam pakan uji. Pakan A merupakan pakan Rusnas, pakan B menggunakan DDGS dan homini dengan total $10,13 \%$, dan pakan $\mathrm{C}$ menggunakan DDGS dan homini dengan total $19,05 \%$.

Untuk pengukuran ketercernaan pakan, digunakan metode pengukuran ketercernaan bahan yang dikemukakan oleh Watanabe (1988), dengan menggunakan kromium oksida sebagai indikator sebanyak 0,5\%. Komposisi pakan penelitian disusun dengan menggunakan program linier dan disajikan pada Tabel 1. Sedangkan hasil analisa proksimat untuk pakan uji serta kandungan asam aminonya disajikan pada Tabel 2 dan 3 .

\section{Ikan uji dan pemeliharaan ikan}

Ikan uji yang digunakan pada penelitian ini adalah ikan kerapu tikus Cromileptes altivelis yang memiliki bobot 11-14 g dan panjang 7-9 $\mathrm{cm}$ yang berasal dari panti benih. Ikan tersebut dipelihara di PT Natuna Karamba, Lampung dan di PT ABM Pulau Seribu. Ikan yang akan digunakan diadaptasikan dengan pakan rusnas sejak ikan berukuran panjang $7 \mathrm{~cm}$. Wadah yang digunakan berupa KJA berukuran $3 \times 1,5 \times 2$ $\mathrm{m}^{3}$ sebanyak enam buah (tiga perlakuan dua 
Tabel 1. Komposisi pakan perlakuan

\begin{tabular}{cccc}
\hline Jenis bahan & Pakan A (\%) & Pakan B (\%) & Pakan C (\%) \\
\hline Tepung ikan & 35,40 & 28,47 & 19,60 \\
DDGS & 0 & 6,13 & 15,05 \\
Homini & 0 & 4 & 4 \\
Bahan lainnya: & 0 & 56,50 & 54,50 \\
Premiks ${ }^{1}$ & 60,50 & 4 & 4 \\
$\mathrm{Cr}_{2} \mathrm{O}_{3}{ }^{2}$ & 4 & 0,50 & 0,50 \\
Total & 0,50 & 100 & 100 \\
\hline
\end{tabular}

Keterangan: MBM: meat bone meal; PMM: poultry meat meal; BK: bungkil kedelai; MI: minyak ikan; ${ }^{1}$ vitamin dan mineral; ${ }^{2}$ hanya untuk pengukuran kecernaaan.

Tabel 2. Hasil analisa proksimat pakan uji

\begin{tabular}{|c|c|c|c|c|c|c|c|c|}
\hline \multirow{2}{*}{$\begin{array}{c}\text { Kode } \\
\text { sampel }\end{array}$} & \multirow{2}{*}{$\begin{array}{c}\text { Kadar } \\
\text { air }\end{array}$} & \multirow{2}{*}{$\begin{array}{c}\text { Kadar } \\
\text { abu }\end{array}$} & \multirow{2}{*}{ Protein } & \multirow{2}{*}{ Lemak } & \multicolumn{2}{|c|}{ Karbohidrat } & \multirow{2}{*}{$\mathrm{Cr}_{2} \mathrm{O}_{3}$} & \multirow{2}{*}{$\begin{array}{c}\text { Energi } \\
\text { (GE/kg) }\end{array}$} \\
\hline & & & & & Serat kasar & BETN & & \\
\hline Pakan A & 0 & 16,8 & 48,59 & 18,54 & 1,94 & 14,2 & 0,59 & 3519 \\
\hline Pakan B & 0 & 16,7 & 46,9 & 19,57 & 2,34 & 14,5 & 0,54 & 3672 \\
\hline Pakan C & 0 & 15,4 & 44,41 & 20,84 & 2,87 & 16,5 & 0,59 & 3693 \\
\hline
\end{tabular}

Tabel 3. Asam amino esensial rasio pada setiap pakan perlakuan

\begin{tabular}{lccc}
\hline & \multirow{2}{*}{ Jenis asam amino $(\%)$} & \multicolumn{3}{c}{ Pakan } \\
\cline { 2 - 4 } & $\mathrm{A}$ & $\mathrm{B}$ & $\mathrm{C}$ \\
\hline Arg & 13,70 & 14,12 & 13,92 \\
Lys & 12,90 & 12,24 & 12,09 \\
Meth+Cys & 8,86 & 8,07 & 7,95 \\
Threo & 8,65 & 8,97 & 9,09 \\
Trp & 2,16 & 2,22 & 2,13 \\
Iso & 8,08 & 8,08 & 8,44 \\
Leu & 14,85 & 15,14 & 15,53 \\
Val & 10,30 & 10,04 & 10,15 \\
Phen+tyr & 15,53 & 15,93 & 15,81 \\
His & 4,99 & 5,19 & 4,88 \\
\hline
\end{tabular}

ulangan). Pakan diberikan dua kali sehari yaitu pukul 08.00 dan 16.00 WIB secara at satiation.

Untuk menjaga terjadinya aliran air di KJA maka jaring dibersihkan setiap hari dengan menggunakan sikat dan setiap 14 hari sekali dilakukan pergantian jaring. Bersamaan pergantian jaring dilakukan sensus terhadap bobot dan jumlah serta dilakukan seleksi ukuran. Sebelum dilakukan sampling ikan dipuasakan terlebih dahulu.

\section{Analisis kimia pakan perlakuan}

Analisis proksimat dilakukan terhadap bahan dan pakan perlakuan. Analisis proksimat yang dilakukan meliputi kadar protein kasar, lemak kasar, serat kasar, abu, air, dan bahan ekstrak tanpa nitrogen (BETN). Keseluruhan analisis proksimat dilakukan di Laboratorium Nutrisi Ikan, Fakultas Perikanan dan Ilmu Kelautan, Institut Pertanian Bogor.

Analisis proksimat untuk protein kasar dilakukan dengan metode Kjeldahl, lemak kering dengan metode Soxchlet, lemak basah dengan metode Folch, abu dengan pemanasan sampel dalam tanur bersuhu 600 ${ }^{\circ} \mathrm{C}$, serat kasar menggunakan metode pelarutan sampel dengan asam dan basa kuat serta pemanasan, dan kadar air dengan metode pemanasan dalam oven bersuhu 105-110 ${ }^{\circ} \mathrm{C}$ (Takeuchi, 1988). Selanjutnya untuk analisis makro mineral kalsium $(\mathrm{Ca})$ dan fosfor (P) dilakukan dengan menggunakan atomic absorption spectrophotometer (AAS). Untuk pengukuran kandungan energi dalam bahan dan pakan (gross energy) dilakukan dengan menggunakan bomb kalorimeter. Sedangkan analisa asam amino dilakukan dengan menggunakan metode Asam amino analyzer.

\section{Analisis ketercernaan pakan}

Pengukuran ketercernaan pakan dilakukan pada akhir penelitian. Pada hari ke lima setelah hewan uji diberi pakan, feses ikan 
mulai dikumpulkan kemudian disimpan dalam botol film. Feses yang sudah terkumpul tersebut disimpan dalam lemari pendingin untuk menjaga kesegarannya.

Pengumpulan feses dilakukan selama enam minggu pemeliharaan. Feses yang telah terkumpul dikeringkan di dalam oven bersuhu $110{ }^{\circ} \mathrm{C}$ selama empat sampai enam jam. Selanjutnya dilakukan analisis kandungan protein dan $\mathrm{Cr}_{2} \mathrm{O}_{3}$ terhadap feses tersebut menggunakan alat spektrofotometer dengan panjang gelombang $350 \mathrm{~nm}$.

\section{Jumlah konsumsi pakan (JKP)}

Jumlah konsumsi pakan (JKP) ditentukan dengan cara menimbang jumlah pakan yang diberikan pada ikan uji setiap hari selama percobaan dilakukan. Pada akhir percobaan, pakan yang telah diberikan dijumlahkan dan dikurangi sisa pakan yang telah dikeringkan.

\section{Ketercernaan nutrien, ketercernaan total, dan ketercernaan energi}

Parameter ketercernaan yang diukur adalah ketercernaan total dan ketercernaan nutrien yang meliputi ketercernaan protein, kalsium (Ca), fosfor (P), dan energi. Nilai ketercernaan nutrien dan ketercernaan total dihitung berdasarkan persamaan yang dikemukakan oleh Takeuchi (1988) dan NRC (1993), yaitu:

$$
\begin{gathered}
\text { Ketercernaan nutrien }=100-\left(1-\frac{\mathrm{a}}{\mathrm{a}^{\prime}} \times \frac{\mathrm{b}^{\prime}}{\mathrm{b}}\right) \\
\text { Ketercernaan total }=100-\left(1-\frac{\mathrm{a}}{\mathrm{a}^{\prime}}\right)
\end{gathered}
$$

Keterangan:

a : \% $\mathrm{Cr}_{2} \mathrm{O}_{3}$ dalam pakan

a' : $\% \mathrm{Cr}_{2} \mathrm{O}_{3}$ dalam feses

$\mathrm{b}: \%$ nutrien dalam pakan

b' : \% nutrien dalam feses

\section{Sintasan (SR)}

Sintasan (SR) dihitung berdasarkan persamaan yang dikemukakan yaitu:

Keterangan:

$$
\mathrm{SR}=\frac{\mathrm{N}_{\mathrm{t}}}{\mathrm{N}_{0}} \times 100 \%
$$

SR : sintasan

$\mathrm{N}_{\mathrm{t}}$ : jumlah ikan pada akhir pemeliharaan

$\mathrm{N}_{0}$ : jumlah ikan pada awal pemeliharaan

\section{Laju pertumbuhan spesifik (LPS)}

Laju pertumbuhan harian ikan uji dihitung berdasarkan persamaan yang dikemukakan oleh Huissman (1987), yaitu:

$$
\alpha=\left(\sqrt[t]{\frac{\mathrm{W}_{\mathrm{t}}}{\mathrm{W}_{0}}}-1\right) \times 100 \%
$$

Keterangan:

$\alpha \quad$ : laju pertumbuhan spesifik (LPS)

$\mathrm{W}_{\mathrm{t}}$ : rata-rata bobot individu pada waktu akhir pemeliharaan $(\mathrm{g})$

Wo: rata-rata bobot individu pada waktu awal pemeliharaan $(\mathrm{g})$

t : lama waktu pemeliharaan (hari)

\section{Efisiensi pakan (EP)}

Efisiensi pakan (EP) dihitung dengan menggunakan rumus sebagai berikut (Lovell, 1989):

$$
\mathrm{EP}=\left(\frac{\left(\mathrm{W}_{\mathrm{t}}+\mathrm{D}\right)-\mathrm{W}_{0}}{\mathrm{~F}}\right)
$$

Keterangan:

EP : efisiensi pakan

$\mathrm{F}$ : jumlah pakan yang diberikan selama pemeliharaan

$\mathrm{W}_{\mathrm{t}}$ : biomassa ikan di akhir pemeliharaan $(\mathrm{g})$

$\mathrm{W}_{0}$ : biomassa ikan di awal pemeliharaan $(\mathrm{g})$

$\mathrm{D}$ : bobot ikan yang mati selama pemeliharaan $(\mathrm{g})$

\section{Retensi lemak}

Nilai retensi lemak dihitung berdasarkan persamaan yang dikemukakan oleh Takeuchi (1988), yaitu:

$$
\mathrm{RL}=\left(\frac{(\mathrm{F}-\mathrm{I})}{\mathrm{L}} \times 100 \%\right)
$$

Keterangan:

$\mathrm{RL}$ : retensi lemak (\%)

$\mathrm{F}$ : jumlah lemak tubuh ikan pada akhir pemeliharaan $(\mathrm{g})$

I : jumlah lemak tubuh ikan pada awal pemeliharaan $(\mathrm{g})$

L : jumlah lemak yang dikonsumsi ikan (g)

\section{Retensi protein (RP)}

Nilai retensi protein dihitung berdasarkan persamaan yang dikemukakan oleh Takeuchi (1988), yaitu:

$$
\mathrm{RP}=\left(\frac{(\mathrm{F}-\mathrm{I})}{\mathrm{P}} \times 100 \%\right)
$$

Keterangan:

RP: retensi protein $(\%)$ 
F : jumlah protein tubuh ikan pada akhir pemeliharaan $(\mathrm{g})$

I : jumlah protein tubuh ikan pada awal pemeliharaan $(\mathrm{g})$

$\mathrm{P}$ : jumlah protein yang dikonsumsi ikan $(\mathrm{g})$

\section{Analisis statistik}

Penelitian ini menggunakan rancangan percobaan berupa rancangan acak lengkap dengan tiga ulangan. Data yang diperoleh dianalisis dengan menggunakan software SPSS 11.5. Analisis ragam dengan tingkat kepercayaan $95 \%$ dan untuk melihat perbedaan perlakuan maka dilakukan uji lanjut dengan uji Duncan.

\section{HASIL}

Data tentang ketercernaan total dan ketercernaan protein pakan perlakuan baik yang diberikan DDGS dan homini (pakan B dan C) maupun tanpa DDGS (pakan A) pada ikan kerapu disajikan pada Tabel 4.

Tabel 4. Ketercernaan total dan ketercernaan protein pakan oleh ikan kerapu tikus Cromileptes altivelis

\begin{tabular}{ccc}
\hline \multirow{2}{*}{ Pakan } & \multicolumn{2}{c}{ Ketercernaan (\%) } \\
\cline { 2 - 3 } & Total & Protein \\
\hline A & 99,43066 & 79,09299 \\
B & 99,40299 & 79,37434 \\
C & 99,44697 & 74,59802 \\
\hline
\end{tabular}

Data tentang LPS, kelangsungan hidup, konsumsi pakan dan konversi pakan ikan kerapu disajikan dalam Tabel 5. Konsumsi pakan benih ikan kerapu tikus semakin menurun dengan peningkatan kandungan DDGS dan Homini dalam pakan. Pakan A tanpa DDGS menunjukkan konsumsi pakan tertinggi yakni sebanyak $18828 \mathrm{~g}$. Penambahan total DDGS dan homini sebesar
$10,13 \%$ (pakan B) memberikan nilai konsumsi pakan yang sama dengan ikan yang diberi pakan A. Selanjutnya peningkatan DDGS sampai $15,05 \%$ dikombinasikan dengan penambahan homini sebesar $4 \%$ (pakan C) menunjukkan nilai konsumsi pakan terkecil dibandingkan dengan ikan yang diberi pakan A dan pakan B $(\mathrm{p}<0,05)$. Selanjutnya ikan kerapu tikus yang diberi pakan memberikan LPS yang paling rendah dibandingkan dengan ikan yang diberi pakan A dan pakan B, sedangkan ikan yang diberi pakan A memberikan LPS yang sama dengan ikan yang diberi pakan B $(\mathrm{p}<0,05)$. Untuk nilai retensi lemak terlihat bahwa benih ikan kerapu yang diberi pakan dengan total kadar DDGS dan homini 10,13\% (pakan B) memberikan nilai retensi lemak yang tertinggi (4,5\%), dibandingkan dengan ikan yang diberi pakan A dan C. Selanjutnya ikan yang diberi pakan $\mathrm{C}$ memiliki RL terendah dibandingkan dengan perlakuan lainnya $(\mathrm{p}<0,05)$.

Nilai EP ikan yang diberi pakan A sebesar 80,3\% lebih besar jika dibandingkan dengan ikan yang diberi pakan $\mathrm{C}$ dan sama jika dibandingkan dengan ikan yang diberi pakan B $(p<0,05)$. Hal yang sama juga terjadi pada parameter sintasan dan RP. Ikan kerapu yang diberi pakan B (kadar DDGS 10,13\%) memberikan hasil yang sama dengan pakan A (kadar DDGS 0\%) dan lebih besar jika dibandingkan dengan ikan yang diberi pakan C (kadar DDGS dan Homini 19,05\%) (Tabel 6) $(\mathrm{p}<0,05)$.

\section{PEMBAHASAN}

Palatabilitas menggambarkan respon penerimaan ikan terhadap pakan yang diberikan. Pakan yang diberikan dalam

Tabel 5. Sintasan (SR), efisiensi pakan (EP), laju pertumbuhan spesifik (LPS), retensi protein (RP), retensi lemak (RL), dan jumlah konsumsi pakan (KP) ikan kerapu tikus Cromileptes altivelis

\begin{tabular}{lccc}
\hline \multirow{2}{*}{ Parameter uji } & \multicolumn{3}{c}{ Pakan } \\
\cline { 2 - 4 } & $\mathrm{A}$ & $\mathrm{B}$ & $\mathrm{C}$ \\
\hline Sintasan $(\%)$ & $94,0 \pm 2,54^{\mathrm{a}}$ & $94,6 \pm 1,70^{\mathrm{a}}$ & $92,8 \pm 1,69^{\mathrm{b}}$ \\
EP $(\%)$ & $80,3 \pm 0,34^{\mathrm{a}}$ & $81,0 \pm 1,00^{\mathrm{a}}$ & $62,5 \pm 0,58^{\mathrm{b}}$ \\
LPS $(\%)$ & $1,8 \pm 0,03^{\mathrm{a}}$ & $1,8 \pm 0,02^{\mathrm{a}}$ & $1,6 \pm 0,02^{\mathrm{b}}$ \\
RP $(\%)$ & $27,0 \pm 0,35^{\mathrm{a}}$ & $27,9 \pm 0,35^{\mathrm{a}}$ & $23,5 \pm 0,22^{\mathrm{b}}$ \\
RL $(\%)$ & $3,9 \pm 0,02^{\mathrm{b}}$ & $4,5 \pm 0,06^{\mathrm{a}}$ & $1,6 \pm 0,05^{\mathrm{c}}$ \\
KP (g) & $18825 \pm 460^{\mathrm{a}}$ & $17750 \pm 495^{\mathrm{b}}$ & $14450 \pm 212^{\mathrm{c}}$ \\
\hline
\end{tabular}

Keterangan: huruf yang berbeda pada baris yang sama menunjukkan perbedaan nyata $(\mathrm{p}<0,05)$. 
komposisi pakan dengan peningkatan kadar DDGS dan homini menurunkan palatabilitas dan akseptabilitas pelet hingga $18 \%$. Secara umum palatabilitas dan akseptabilitas akan menurun dengan peningkatan bahan-bahan nabati dalam komposisi pakan. Deteksi pakan, palatabilitas, dan akseptabilitas pelet untuk pakan akuatik sangat dipengaruhi oleh ketersediaan atraktan dalam pakan. Sistem deteksi kemo reseptor pada ikan maka deteksi pakan oleh ikan sangat tergantung dari ketersediaan asam amino bebas di pakan seperti bitain, asam glutamat, alanin dan glisin (Akiyama et al., 1992).

Penggantian komposisi dengan memasukkan DDGS (sumber protein nabati) sebesar $10,13 \%$ dan $19,05 \%$ dalam pakan diduga akan mengurangi ketersediaan asam amino bebas sehingga menurunkan respon ikan terhadap pelet baik untuk mencari (deteksi) maupun rasa (palatabilitas). Hal yang sama juga terjadi pada ikan gurami Osphronemus goramy yang diberi pakan dengan sumber protein nabati (Suprayudi et al., 1999). Peningkatan kadar DDGS dan homini dalam pakan $10,13 \%$ dan $19,05 \%$ (pakan B dan pakan C) terlihat berpengaruh nyata terhadap nilai ketercernaan nutrien (Tabel 4). Ketercernaan nutrien pada ikan dipengaruhi oleh beberapa faktor seperti kandungan nutrien terutama serat dan kandungan zat anti nutrisi khusus fitat (yang terdapat pada jagung).

Jika dibandingkan dengan bahan baku hewani maka nilai ketercernaan bahan baku nabati lebih rendah, khususnya untuk ikanikan karnivora (Suprayudi et al., 2004). Hasil ketercernaan protein pada penelitian ini memperlihatkan fenomena yang sama dimana peningkatan persentase DDGS dan homini dalam pakan meningkatkan kandungan serat dalam pakan dan menurunkan ketercernaan protein (Tabel 4).

Nilai retensi merupakan gambaran jumlah nutrien yang mampu diserap dari dalam pakan untuk disimpan di dalam tubuh. Protein dan lemak merupakan nutrien yang dapat berfungsi sebagai sumber energi selain karbohidrat. Lovell (1989) mengungkapkan bahwa ikan lebih efisien menggunakan protein sebagai sumber energi. Pada ikan bawal, retensi protein dan retensi lemak pada ketiga perlakuan menunjukkan hasil yang tidak berbeda nyata. NRC (1993) dan Halver (2002), menyatakan bahwa kelebihan energi yang ada dapat disimpan dalam bentuk protein atau lemak. Ketika terjadi keterbatasan nutrisi esensial maka sintesis protein akan terhenti dan kelebihan energi akan disimpan dalam bentuk lemak. Selanjutnya Suprayudi et al. (2000) menyatakan bahwa disamping kadar protein, lemak, dan karbohidrat dalam pakan maka perbedaan retensi protein disebabkan oleh kualitas protein, yakni komposisi asam amino. Penelitian ini dirancang dengan pakan perlakuan yang mengandung isoprotein dan isoenergi serta lemak yang sama. Rendahnya retensi protein pada ikan yang diberi pakan $\mathrm{C}$ (DDGS dan Homini 19,05\%) (Tabel 5) disebabkan oleh rendahnya kadar metionin dan sistein dalam pakan $\mathrm{C}$ dibandingkan dengan pakan A dan pakan B. Peningkatan kadar DDGS dan homini sampai 19\% menurunkan kandungan metionin dan sistein dalam pakan hingga $5 \%$ dibandingkan dengan pakan $\mathrm{A}$ dan 3\% dibandingkan dengan pakan B (Tabel 3). Asam amino metionin dan sistein menjadi asam amino pembatas utama pada pakan C (Tabel 3). Rendahnya kedua asam amino tersebut menjadi penyebab rendahnya nilai retensi protein pada ikan yang diberi pakan $\mathrm{C}$ $(23,5 \%)$ dibandingkan dengan ikan yang diberi pakan A dan B (27\% dan 27,9\%). Rendahnya nilai retensi lemak pada ikan baik yang diberi pakan A, B, dan C memperlihatkan bahwa ikan kerapu mampu memanfaatkan lemak sebagai sumber energi.

Dengan semakin baiknya palatabilitas, akseptabilitas, dan rendahnya energi untuk metabolik maka energi yang disimpan akan semakin tinggi. Tingginya energi yang disimpan (net energy) dapat dijadikan indikator efisiensi pakan. Nilai efisiensi pakan pada perlakuan A dan B lebih tinggi dibandingkan dengan perlakuan $\mathrm{C}$. Hal ini menunjukkan bahwa pakan A dan B dicerna lebih baik (Tabel 5) dibanding pakan C. Selanjutnya pakan A dan B diduga memiliki lebih sedikit energi yang hilang dalam bentuk panas akibat aktivitas metabolisme dari asam amino (Tabel 2) dibandingkan dengan pakan C. Nilai efisiensi pakan yang tinggi 
menunjukkan meningkatnya nilai konversi pakan menjadi daging yang merupakan indikator pertumbuhan. Nilai efisiensi pakan berkorelasi positif dengan LPS, terlihat pada pakan A dan B memiliki nilai LPS yang lebih baik dibandingkan pakan $\mathrm{C}$ (Tabel 5).

Nilai sintasan pada ikan yang diberi pakan A (94\%) sama dengan ikan yang diberi pakan B $(94,6 \%)$, namun lebih besar dari ikan yang diberi pakan C (92,8\%) (Tabel 5). Rendahnya sintasan ikan yang diberi pakan C diduga terjadi akibat cekaman metabolis yang disebabkan oleh kurang seimbangnya nutrien dalam pakan C. Halver (2002) menyatakan bahwa pada beberapa ikan air tawar dan laut terjadi cekaman nutrien yang dapat menyebabkan penurunan pertumbuhan dan rendahnya nilai sintasan.

\section{KESIMPULAN}

Berdasarkan hasil penelitian ini dapat disimpulkan bahwa ikan kerapu dapat memanfaatkan dengan baik pakan yang mengandung total DDGS dan homini sebesar $10,13 \%$ dan dapat mensubstitusikan kedelai dan terigu.

\section{DAFTAR PUSTAKA}

Akiyama DM, Warren GD, Addison LL. 1992. Penaeid Shrimp Nutrition. Tokyo, Japan: Elsevier.

Halver JE. 2002. State of World Aquaculture. FAO Fisheries Technical Paper 500. Rome, Italy: IWAS/FRD, FAO Fisheries Department.

Hardy RW. 2006. Worldwide fish meal production outlook and the use of alternative protein meals for aquaculture. In: Cruz-Suárez LE, Ricque-Marie $\mathrm{D}$, Tapa-Salazar M, Nieto-López M, Villarreal-Cabazos D, Puello-Cruz A, García-Ortega A. (eds). Avances en Nutrición Acuícola VIII. Memorias del VIII Simposio Internacional de Nutrición Acuícola. November 15-17, 2006. Mazatlán, Sinaloa, México.

Hertrampf JW, Piedad-Pascual F. 2000. Handbook on Ingredients for Aquaculture Feeds. Dordrecht, Boston, London: Kluwer Academic Publishers.
Huissman EA. 1987. Principle of Fish Production. The Netherlands: Departement of Fish Culture and Fisheries, Wageningen Agricultural University.

Lovell T. 1989. Nutrition and Feeding of Fish. New York, USA: Van Nostrand Reinhold.

[NRC] National Research Council. 1993. Nutrient Requirement of Fish. Washington DC, USA: National Academy Press.

Suprayudi MA. 2010. Pengembangan Bahan Baku Lokal Untuk Pakan Ikan Udang, Status Terkini dan Prospeknya. Lokakarya Pakan Nasional, Ikatan Sarjana Perikanan Indonesia-Balai Riset Perikanan dan Kelautan, Kementrian Perikanan dan Kelautan.

Suprayudi MA, Bintang M, Takeuchi T, Mokoginta I, Sutardi, T. 1999. Defatted soybean meal as an alternative source to substitute fish meal in the feed of giant gourami, Osphronemus gouramy Lac. Suisanzoshoku 47: 551-557.

Suprayudi MA, Takeuchi T, Mokoginta I, Kartikasari A. 2000. The effect of additional arginine in the high deffated soybean meal diet on the growth of giant gouramy Osphronemus gouramy Lac. Fish. Sci. 66: 807-811.

Suprayudi MA, Yaniharto D, Mokoginta I, Jusadi D, Sumule O. 2004. The Effect of High Deffated Soybean Meal in the Diet of Giant Grouper With and Without Taurin Supplementation. Presented in World Aquaculture Symposium, Bali, Indonesia.

Takeuchi T. 1988. Laboratory work chemical evaluation of dietary nutriens. In: Watanabe $\mathrm{T}$ (ed). Fish Nutrition and Mariculture. Tokyo, Japan: Department of Aquatic Biosience. Tokyo University of Fisheries. JICA. pp: 179-226.

Tangendjaja B, Wina E. 1998. Limbah tanaman dan produk samping industri jagung untuk pakan. www.balitsereal. litbang.deptan.go.id /bjagung/duadua.pdf. [1 Mei 2009].

Watanabe T. 1988. Fish Nutrition and Mariculture. Tokyo, Japan: Department of Aquatic Biosience, Tokyo University of Fisheries. 
Zhou P, Zhang W, Davis DA, Lim C. 2010. Growth respons and feed utilization of juvenile hybrid catfish fed diets containing distiller's dried grain with soluble to replace a combination soybean meal and corn meal. North American Journal of aquaculture 72: 298-303. 